Abstract P0-1021 Table 1 Symptom profile of children in the CAP cohort

\begin{tabular}{|c|c|c|}
\hline \multirow{2}{*}{\multicolumn{2}{|c|}{$\begin{array}{l}\text { Presenting symptoms } \\
\text { History of episodic cough }\end{array}$}} & \multirow{3}{*}{$\begin{array}{l}594(99 \%) \\
366(61 \%)\end{array}$} \\
\hline & & \\
\hline & Presence of Dry cough & \\
\hline & Predominantly Nigh-time coügh & $407(68 \%)$ \\
\hline & Predominantly Day-time cough & $59(10 \%)^{---}$ \\
\hline & No diümal variation in cough & $128(214 \%)$ \\
\hline \multicolumn{2}{|c|}{ History of episodic whesing } & $468(78 \%)$ \\
\hline & Predominantly Nigh-time whaesing & $332(71 \%)$ \\
\hline & Predominantly Day-time wheazing & $46(10 \% 6)$ \\
\hline & No diumal variation in whèving & $90(19 \%)$ \\
\hline \multirow{2}{*}{\multicolumn{2}{|c|}{$\begin{array}{l}\text { Limitation in activity play } \\
\text { Chest tightness (among } 352 \text { chilaren }>60 \mathrm{mo} \text { ) }\end{array}$}} & $433(72 \%)$ \\
\hline & & $38 / 352(11 \%)$ \\
\hline \multicolumn{2}{|c|}{ Associated symptomis suggesting atopy } & $359(0056)$ \\
\hline \multicolumn{2}{|c|}{ Nasar symptoms, n (\%) } & $254(42 \%)$ \\
\hline & Frequent eqpisodes of rüny nose & $201(79 \%)$ \\
\hline & Episodic sneäzing & $113(45 \%)^{-}$ \\
\hline & Itchy nose & $31(12 \%)$ \\
\hline & Blocked nose- & $9(4 \%)$ \\
\hline \multicolumn{2}{|c|}{ SWin symptoms } & $90(15 \%)$ \\
\hline & Cunrent diagnosis of atopic dermatitis & $23(26 \%)$ \\
\hline & Previous diagnosis of atopic dematitis & $49(54 \%)$ \\
\hline & Undiagnoeded previous itchy alsin lesions & $18(20 \%)$ \\
\hline \multicolumn{2}{|c|}{$\begin{array}{l}\text { Eye symptoms } \\
\text { Y Frequent eyje watering and redineass }\end{array}$} & $35(6 \%)$ \\
\hline & Frequent eye watering and rediness & $29(8396)$ \\
\hline & Itching in eyes & $25(71 \%)$ \\
\hline & Pain in eyes & $6(17 \%)$ \\
\hline \multicolumn{3}{|c|}{ Othersymptouns } \\
\hline \multicolumn{2}{|c|}{ Gastro-intestinal symptoms, n (\%) } & $108(18.1)$ \\
\hline & Symptoms suggesting reflux & $73(68 \%)$ \\
\hline & Vague abdomina pain & $21(19 \%)$ \\
\hline & Altered bowel habits & $14(13 \%)$ \\
\hline \multirow{2}{*}{\multicolumn{2}{|c|}{$\begin{array}{l}\text { Chest pain (non-spacific) } \\
\text { Family history of atopv (first degree relative) }\end{array}$}} & \multirow{2}{*}{$\begin{array}{ll}25(496) \\
382(6296)\end{array}$} \\
\hline & & \\
\hline & Asthma & $154(40 \%)$ \\
\hline & Amergic shinitis & $209(55 \%)$ \\
\hline & Skin allergy & $19(5 \%)$ \\
\hline & Combination of any of the above & $63(16 \%)$ \\
\hline
\end{tabular}

Abstract P0-1021 Table 2 Parental perception of exacerbating and relieving factors in the CAP report

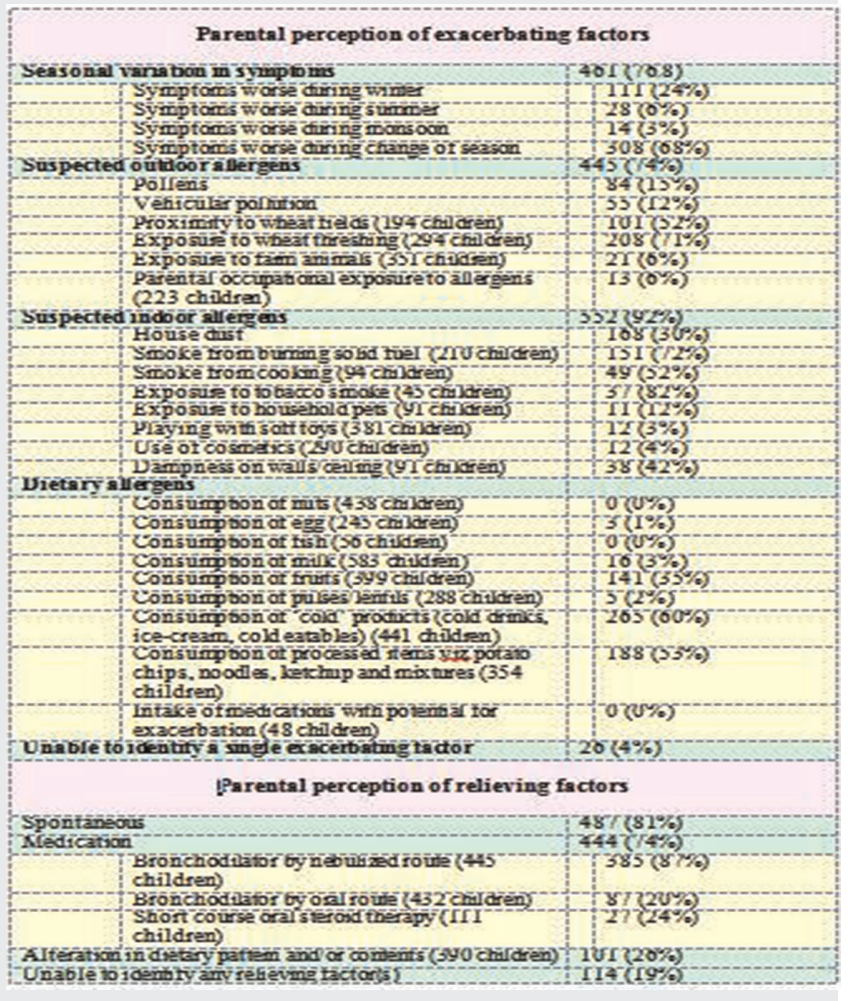

Classification of severity, treatment plan, follow-up protocol and monitoring of response were as per GINA Guideline.

Results The mean age of enrolled children was 73.4 months (range 3-144) and mean age of symptom onset was 45.0 months (range3.0-75.0). The age distribution was: $<12$ months (20, $3.3 \%), 12-60$ months (228,38.0\%), 60-144 months (352, $58.7 \%)$. The male:female ratio was 2.7 . Severity classification was: Mild intermittent-12.0\%, Mild persistent-18.0\%, Moderatepersistent- $63 \%$, Severe persistent-7\%. Table 1 summarises the symptom profile and Table 2 shows parental perception of exacerbating/relieving factors.

Conclusion These observations suggest that childhood asthma phenotype in a developing country setting is distinct from developed countries.

\section{PO-1022 CORRELATION OF PHENOTYPIC EXPRESSION WITH RESPONSE TO THERAPY IN INDIAN CHILDREN WITH BRONCHIAL ASTHMA}

JL Mathew, S Paikray, M Singh. Advanced Pediatrics Centre, Post Graduate Institute of Medical Education and Research, Chandigarh, India

\subsection{6/archdischild-2014-307384.1638}

Background Clinical experience suggests that asthmatic children in developing countries have a different phenotype and therapeutic response than in developed countries.

Objective To correlate therapeutic response in childhood asthma with phenotypic features.

Methods 180 children in the Childhood Asthma Phenotype (CAP) cohort ( $\mathrm{n}=600$, age $<12 \mathrm{y}$, diagnosis based on NAEPR III Guidelines) underwent evaluation of phenotypic characteristics using a pre-tested semis-structured questionnaire. Classification of severity, treatment plan, follow-up protocol and monitoring of response were done as per GINA Guideline. Response to therapy was assessed 6 months after initiating treatment and modifying the drug/dose as required. Disease control was defined as per GINA.

Results The mean age of enrolled children was $81.4 \mathrm{mo}$ (range 3.0 to 144.0 ) with age distribution $<12$ months $=9$, 12-60

Abstract P0-1022 Table 1 Distribution of characteristics in children with uncontrolled versus controlled disease

\begin{tabular}{|c|c|c|c|c|}
\hline \multicolumn{2}{|l|}{ torizontal (Category) Axis } & \begin{tabular}{|l|} 
Disease \\
Uncontrolled \\
$\mathbf{n}=\mathbf{2 3}$
\end{tabular} & $\begin{array}{l}\text { Disease } \\
\text { Controlled } \\
\mathrm{n}=127\end{array}$ & $\begin{array}{l}\text { Odds ratio } \\
(95 \% \text { C.I) }\end{array}$ \\
\hline \multirow[t]{2}{*}{ Gender } & Male (n) & $15(13.40 \%)$ & $97(86.60 \%)$ & \multirow[t]{2}{*}{$0.58(0.22,1.50)$} \\
\hline & Female (n) & $8(21.05 \%)$ & $30(78.95 \%)$ & \\
\hline \multirow[t]{2}{*}{ Age } & $<$ 1year $(\mathrm{n}, \%)$ & $8(22.2 \%)$ & $28(77.8 \%)$ & \multirow[t]{2}{*}{$1.86(0.66,5.20)$} \\
\hline & $1-5$ year $(n, \%)$ & $10(13.3 \%)$ & $65(86.7 \%)$ & \\
\hline \multirow[t]{2}{*}{ Cough duration } & $>12$ months & $19(82.6 \%)$ & $88(69.8 \%)$ & \multirow[t]{2}{*}{$2.11(0.67,6.60)$} \\
\hline & $<12$ months & $4(17.4 \%)$ & $39(30.2 \%)$ & \\
\hline \multirow[t]{2}{*}{ Wheeze } & $>12$ months & $17(73.9 \%)$ & $59(46.5 \%)$ & \multirow[t]{2}{*}{$3.27(1.20,8.82)$} \\
\hline & $<12$ months & $6(26.08 \%)$ & $68(53.5 \%)$ & \\
\hline \multirow{2}{*}{$\begin{array}{l}\text { Night time } \\
\text { symptoms }\end{array}$} & Present & $12(75 \%)$ & $54(42.5 \%)$ & \multirow[t]{2}{*}{$33.55(9.25-121.71)$} \\
\hline & Absent & $11(8.2 \%)$ & $89(70.1 \%)$ & \\
\hline \multirow[t]{2}{*}{ History of atopy. } & Present & $12(52.17 \%)$ & $65(51.18 \%)$ & \multirow[t]{2}{*}{$1.04(0.42,2.53)$} \\
\hline & Absent & $11(47.83 \%)$ & $62(48.82 \%)$ & \\
\hline \multirow{2}{*}{$\begin{array}{l}\text { Family history of } \\
\text { asthma }\end{array}$} & Present & $11(47.8 \%)$ & $73(57.5 \%)$ & \multirow[t]{2}{*}{$0.68(0.28,1.65)$} \\
\hline & Absent & $12(52.2 \%)$ & $54(42.5 \%)$ & \\
\hline \multirow{2}{*}{$\begin{array}{l}\text { Family history of } \\
\text { atopy. }\end{array}$} & \begin{tabular}{|l|} 
Present \\
\end{tabular} & $17(17.0 \%)$ & $83(83.0 \%)$ & \multirow[t]{2}{*}{$1.50(0.55,4.08)$} \\
\hline & Absent & $6(12.0 \%)$ & $44(88.0 \%)$ & \\
\hline \multirow{2}{*}{$\begin{array}{l}\begin{array}{l}\text { Seasonal } \\
\text { exacerbation }\end{array} \\
\end{array}$} & Present & $18(16.51 \%)$ & $91(83.49 \%)$ & \multirow[t]{2}{*}{$1.42(0.49,4.12)$} \\
\hline & Absent & $5(12.20 \%)$ & $36(87.80 \%)$ & \\
\hline \multirow{2}{*}{$\begin{array}{l}\begin{array}{l}\text { Exposure to } \\
\text { outdoor allergens }\end{array} \\
\end{array}$} & Present & $16(16.50 \%)$ & $81(83.50 \%)$ & \multirow[t]{2}{*}{$1.30(0.50,3.39)$} \\
\hline & Absent & $7(13.21 \%)$ & $46(86.79 \%)$ & \\
\hline \multirow{2}{*}{$\begin{array}{l}\text { Exposure to } \\
\text { indoor allergens }\end{array}$} & Present & $19(82.6 \%)$ & $89(70.1 \%)$ & \multirow[t]{2}{*}{$0.80(0.31,2.02)$} \\
\hline & Absent & $8(19.0 \%)$ & $34(80.9 \%)$ & \\
\hline
\end{tabular}


months $=111,60-144$ months $=180$. Severity classification: Mild intermittent $=33$, Mild persistent $=61$, Moderate persistent $=181$, Severe persistent $=25$. Children with persistent asthma received inhaled corticosteroid with $(26 \%)$ or without $(74 \%)$ long-acting-bronchodilator or Leukotriene-receptor-antagonist. Those with intermittent asthma received short course of bronchodilator. After $6 \mathrm{mo}$, disease control could be assessed in 150 children who had at least $90 \%$ adherence to the prescribed treatment. Table1 shows the distribution of demographic features, symptom profile, personal and family atopy, and exacerbating/ triggering factors, in children with uncontrolled versus controlled disease.

Conclusion With the exception of night time symptoms at presentation, there are no specific features that can predict poor response to therapy in children with bronchialasthma.

\section{P0-1023 OVER-PRESCRIPTION OF ADRENALINE AUTO-INJECTORS IN SCHOOL AGE CHILDREN?}

G McCall, D Watkins, J Hughes. Paediatrics, Antrim Hospital, Belfast, UK

\subsection{6/archdischild-2014-307384.1639}

Anaphylaxis is an acute, potentially life-threatening condition. Referral to specialist allergy services is vital to allow identification of triggers involved. One of the key purposes of these clinics is prescription of rescue medication, which can include adrenaline auto-injectors.

Aim We reviewed all patients who attended the Paediatric Allergy Clinic and were supplied with an adrenaline auto-injector over the period of January 2008-December 2013. We aimed to compare this number with the number of children with anaphylaxis care-plans in schools within the Northern Health and Social care trust.

Method We reviewed all submissions to the Adrenaline Autoinjector log-book. This is held at the Paediatric Allergy Clinic and completed each time a patient is seen who has been prescribed an adrenaline auto-injector. Information was obtained from the Public Health nursing team to ascertain the number of children with an anaphylaxis care-plan for school.

Results In 2013 there were 49,286 children aged between 5-16 years within the NHSCT; 580 children were identified with an anaphylaxis care-plan held in school. Prevalence of school aged children at risk of anaphylaxis was 1.2\%. Only 160 children (from birth to 18 years), with adrenaline auto-injector devices were reviewed at the allergy clinic in 2013, with 157 reviewed in 2012.

Between January 2008 and December 2013 there was six fold increase in patients seen at the Paediatric Allergy Clinic. We reviewed a total of 476 submissions to the Adrenaline Autoinjector logbook; 339 new patients and 137 review patients. There were no specific trends identified with regard to gender but there was a majority of patients under 5 yrs. There was a predominance of nut allergy in the new and review patients. Of the 68 new patients identified with an egg allergy $18 \%$ had a sole egg allergy, all of who had been prescribed an adrenaline auto-injector.

Conclusion There is a major shortfall with regard to the total number of children within the Northern HSCT who have been prescribed an adrenaline auto-injector and those who are seen at the Paediatric Allergy Clinic. This study has focused future efforts to review each of these patients in a formal paediatric allergy setting.

\section{PO-1024 THE IMPORTANCE OF PROINFLAMATORY CYTOKINE'S IN IMMUNE RESPONSE IN MYCOPLASMA PNEUMONIAE INFECTION IN CHILDREN WITH BRONHOPULMONARY AFFECTION}

${ }^{1} \mathrm{~L}$ Neamtu, ${ }^{2} \mathrm{O}$ Tagadiuc, 'S Sciuca. 'Department of Pediatrics, State Medical and Pharmaceutical University, Chisinau, Moldova; 'Laboratory of Biochemistry, State Medical and Pharmaceutical University, Chisinau, Moldova

10.1136/archdischild-2014-307384.1640

Aims Our study was to evaluate proinflammatory cytokine's (IL-2) interaction with humoral immunity in children with $\mathrm{Myco}$ plasma pneumoniae lower respiratory tract infection.

Methods The study group included 20 children, aged 5 months - 7 years, with pneumonia and wheezing induced by $\mathrm{Myco-}$ plasma pneumoniae infection. The diagnosis of M.pneumoniae was based on clinical, radiological and on the immunological determinations of specific antibodies in diagnosis titers. Levels of IgA, IgM, IgG, IL-2 were determined in serum samples obtained from all children and were tested by ELISA.

Results IL-2 levels in children with Mycoplasma-positive bronchopulmonary disease was 36,51 $\pm 2,26 \mathrm{pg} / \mathrm{ml}$ (variation $20,0-100,85 \mathrm{pg} / \mathrm{ml}$ ) and it is higher, than in healthy children (variation 2,44-7,2 pg/ml) pg/ml. In study group average level of IgA was $0,96 \pm 0,13 \mathrm{~g} / \mathrm{l}$ did not differ from levels of $\operatorname{IgA}$ in healthy children $(\operatorname{IgA} 0,9 \pm 0,04 \mathrm{~g} / \mathrm{l})$. But level of serum $\operatorname{IgM}$ was higher $(\mathrm{p}<0,05)$ in $M p$-positive group $(1,8 \pm 0,16 \mathrm{~g} / \mathrm{l})$ in comparison with levels of $\operatorname{IgM}$ in healthy children $(1,2 \pm 0,1 \mathrm{~g} /$ 1). In study group level of $\operatorname{IgG}$ was higher $(9,47 \pm 0,67 \mathrm{~g} / \mathrm{l}$; $\mathrm{p}<0,05)$ in comparison with age norms $(7,5 \pm 0,1 \mathrm{~g} / \mathrm{l})$.

Conclusion Inflammatory processes in children with $\mathrm{Myco}-$ plasma pneumoniae infection are characterised by hyper production of IL-2, and they are associated with high serum levels of IgM, IgG.

\section{PO-1025 PERSISTENT WHEEZING CASES AND TREATMENT WITH INTRAVENOUS IMMUNOGLOBULIN DURING INFANCY}

O Özdemir, S Bozdogan Polat. Pediatric Allergy and Immunology, Sakarya University Medicine Faculty Researh and Education Hospital, Sakarya, Turkey

\subsection{6/archdischild-2014-307384.1641}

Background When a physician comes across patients with recurrent wheezing are resistant to $\beta 2$-agonist and anti-cholinergic therapy, known as atypical wheezing cases; he should investigate for hypogammaglobulinemia in these patients.

Aim Here, 3 cases are reported to make paediatricians aware of hypogammaglobulinemia, which is one of the reasons causing recurrent and persistent wheezing attacks during infancy and beyond.

Case presentations Case 1: 24 month-old girl presented to us with complaining of coughing and persistent wheezing. Her symptoms persisted even though she was using religiously nebulized salbutamol+budesonid therapy. Before this episode, she had 9 other wheezing attacks in her past medical history beginning from 2 months of age. Low IgG level $(358 \mathrm{mg} / \mathrm{dl})$ was detected at two different times. At the fourth day of admission, she was given IVIG $500 \mathrm{mg} / \mathrm{kg} / \mathrm{dose}$. Case 2: 8-month-old girl came to our outpatient clinic with complaints of coughing and wheezing. Despite routine therapy, wheezing persisted for 2 months and wheezing severity increased and it did not respond to $\beta 2$-agonist therapy. Low IgG level $(304 \mathrm{mg} / \mathrm{dl}$ ) was detected at two different times. At the 15 th day of admission, she was 